\title{
The influence of the duration of in vitro maturation and incubation with an activating agent on the hatching capacity of bovine parthenotes - short communication
}

\author{
Ernesto Orozco-Lucero ${ }^{1 \#}$, Bianca V. Orozco-Galindo ${ }^{1 \#}$, Juan A. Quintero-Elisea ${ }^{1}$, \\ Mateo F. Itza-Ortiz ${ }^{1}$, Marbella Chavez-Solano², José M. Carrera-Chávez ${ }^{1}$, \\ Armando Varela-Ramirez ${ }^{3}$, and Andrés Quezada-Casasola ${ }^{1 *}$ \\ ${ }^{1}$ Department of Veterinary Sciences, Biomedical Sciences Institute, Autonomous University of Ciudad Juarez, \\ Ciudad Juarez, Chihuahua, Mexico \\ ${ }^{2}$ Department of Chemical and Biological Sciences, Biomedical Sciences Institute, Autonomous University of Ciudad \\ Juarez, Ciudad Juarez, Chihuahua, Mexico \\ ${ }^{3}$ Border Biomedical Research Center, Department of Biological Sciences, University of Texas at El Paso, \\ El Paso, TX, USA
}

OROZCO-LUCERO, E., B. V. OROZCO-GALINDO, J.A. QUINTERO-ELISEA, M. F. ITZA-ORTIZ, M. CHAVEZ-SOLANO, J. M. CARRERA-CHÁVEZ, A. VARELA-RAMIREZ, A. QUEZADA-CASASOLA: The influence of the duration of in vitro maturation and incubation with an activating agent on the hatching capacity of bovine parthenotes - short communication. Vet. arhiv 90, 527-534, 2020.

\section{ABSTRACT}

The period of both in vitro maturation (IVM) and incubation with oocyte activators affects the blastocyst yield following parthenogenetic activation (PA). Nevertheless, it is still unknown how these conditions impact the expansion and hatching rates of bovine parthenogenetic blastocysts. The objective of this study was to assess the influence of the duration of IVM and exposure to the activating agent, 6-dimethylaminopurine (6-DMAP), on a number of developmental parameters in bovine parthenotes, including: Cleavage, blastocyst formation, expansion, and hatching. Slaughterhouse oocytes were subjected to different periods of IVM. Subsequently, eggs were first parthenogenetically activated for five minutes with ionomycin and then incubated for distinct lengths of time with a second activator, 6-DMAP. The treatments were: a) Control: 22 h IVM/4 h 6-DMAP; b) 22 h IVM/5 h 6-DMAP; c) 24 h IVM/4 h 6-DMAP; and d) 24 h IVM/5 h 6-DMAP. Developmental stages were evaluated at day 4 and day 8 of in vitro culture (IVC). No differences were detected in most developmental parameters. However, the duration of IVM and incubation with 6-DMAP significantly affected $(\mathrm{P}<0.05)$ hatching capacity considering the number of blastocysts (Hatch./Blast.). Also, this same variable was higher $(\mathrm{P}<0.05)$ in group b) $22 \mathrm{~h}$ IVM/5 h 6-DMAP $(45.89 \pm 12.59 \%)$, as compared to c) $24 \mathrm{~h} \mathrm{IVM} / 4 \mathrm{~h}$ 6-DMAP $(6.67 \pm 6.67 \%)$. In conclusion, the length of IVM and incubation with 6-DMAP influenced parthenogenetic development, where $22 \mathrm{~h}$ IVM/5 h 6-DMAP was the condition producing the highest Hatch./Blast. rate in bovine parthenotes.

Key words: in vitro maturation; 6-dimethylaminopurine; culture length; parthenogenesis; bovine

\#Both authors contributed equally

\footnotetext{
*Corresponding author:

Andrés Quezada-Casasola, DVM, PhD, Departament of Veterinary Sciences, Biomedical Sciences Institute, Autonomous University of Ciudad Juarez, Anillo Envolvente Pronaf y Estocolmo s/n, Ciudad Juarez 32310, Mexico; +52 6566881800 X 1667; Fax: +52 656 688-1825; E-mail: aquezada@uacj.mx
} 


\section{Introduction}

In vitro embryo production (IVP) is widely employed as a physiological study model. Results obtained from embryos generated by in vitro fertilization (IVF) are complemented with research of embryos generated by parthenogenetic activation (PA) (MUÑOZ et al., 2015). Parthenotes are embryos produced after induction of egg cell division in the absence of a spermatozoon. Due to the absence of a paternal genome, experimentallyproduced parthenotes usually do not yield viable offspring upon transfer to foster mothers (BREVINI et al., 2012). Moreover, the in vitro parthenogenetic developmental rates are generally lower than those of IVF-embryos during the first eight days of in vitro culture (IVC) (NAKAMURA and KIKUCHI, 2017). Therefore, strategies to improve results obtained from PA systems are still required.

As indicated by ANCCO et al. (2015), similar to IVP, experimental parthenogenesis relies on both IVM and IVC. PAcan be carried out by egg membrane depolarization using chemical stimulation (e.g., strontium, ethanol, calcium ionophores), blockage of the extrusion of the second polar body, or by a chemically-induced decrease in the activity of maturation promoting factor (MPF) (DE MACEDO et al., 2019). An example of the last strategy is the inhibition of kinases by 6-dimethylaminopurine (6-DMAP) (LEE et al., 2018). It has been reported that the duration of both IVM and egg activation, as well as the type of chemical activating agent (or the combination of several of them), influences the developmental outcome of bovine parthenotes. Such chemical induction might include a first step of activation with ionomycin, a calcium ionophore, followed by incubation with 6-DMAP as a second activator (MÉO et al., 2007). Nevertheless, it is not yet evident in which way the incubation time during IVM and PA affects the course of parthenogenesis, beyond initial blastocyst formation, namely expansion and hatching. This could probably be due to the gradual inhibition of MPF activity upon longer periods of both IVM and incubation with kinase inhibitors (BASTOS et al., 2008). In this regard, it has been recently reported that insecticide- induced suppression of MPF activity interferes with parthenogenetic blastocyst expansion and hatching in pigs (NIE et al., 2019). Consequently, we hypothesized that the length of IVM and PA involving MPF activity suppression, influences bovine parthenote developmental parameters, including expansion and hatching. Thus, the objective of the present study was to explore how distinct periods of both IVM and MPF inhibition impact the course of bovine parthenogenesis, in terms of cleavage, expanded blastocyst, and hatching rates, to improve PA protocols in cattle.

\section{Materials and methods}

All chemicals were purchased from SigmaAldrich $^{\circledR}$ (St. Louis, MO), whereas the culture media were from IVF Bioscience (Falmouth, UK), unless otherwise stated.

Oocyte collection. One hundred and sixtyfive bovine ovaries were obtained from a local slaughterhouse according to the NOM-051ZOO-1995 and NOM-033-ZOO-1995 national animal welfare guidelines. Collected ovaries were transported to the laboratory in $0.9 \%(\mathrm{w} / \mathrm{v}) \mathrm{NaCl}$ at $29-35{ }^{\circ} \mathrm{C}$. Follicles of $2-8 \mathrm{~mm}$ in diameter were aspirated using a 20-gauge needle after 2-3 $\mathrm{h}$ postmortem. The collected follicular fluid was heparinized (5 IU/mL; Pisa ${ }^{\circledR}$, Guadalajara, México).

In vitro maturation. Cumulus-oocyte-complexes (COCs) were washed three times in BO-WASH medium at $37{ }^{\circ} \mathrm{C}$. COCs of categories 1 to 3 (full-size oocytes with homogeneous cytoplasm; multiple layers of cumulus showing no expansion, without or with just slight signs of peripheral atresia) were selected (BLONDIN and SIRARD, 1995). Subsequently, the COCs were placed in previously equilibrated BO-IVM, at a density of $45 \mathrm{COCs} / 500 \mu \mathrm{L}$. The COCs were matured in vitro at $38.5{ }^{\circ} \mathrm{C} / 6.5 \% \mathrm{CO}_{2} / 100 \%$ relative humidity $(\mathrm{RH})$ either for $22-$ or $24 \mathrm{~h}$, according to the treatment.

Parthenogenetic activation. For denudation purposes, mature COCs were placed in BO-WASH at $37{ }^{\circ} \mathrm{C}$, and supplemented with $0.33 \mathrm{mg} / \mathrm{mL}$ hyaluronidase. Then, the oocytes were denuded 
with a micropipette and washed twice in BO-WASH without hyaluronidase. Groups of 10-40 oocytes were immersed in $50 \mu \mathrm{L}$-droplets of equilibrated (in the incubator) BO-IVF medium, containing 5 $\mu \mathrm{M}$ ionomycin, and covered with mineral oil. This initial activation step was performed at $38.5^{\circ} \mathrm{C} / 6.5 \%$ $\mathrm{CO}_{2} / 100 \% \mathrm{RH}$ for $5 \mathrm{~min}$. The instant when the oocytes started incubation with the ionophore was considered as $0 \mathrm{~h}$ post-parthenogenetic activation (0 hPA). Following the first activation, presumptive zygotes (p-Zy) were washed three times in BOWASH. After that, the p-Zy were exposed to 6-DMAP as a second activating agent (MÉO et al., 2007; BASTOS et al., 2008). Around 10-40 p-Zy were introduced in droplets of $50 \mu \mathrm{L}$ of BO-IVF supplemented with $2.8 \mathrm{mM}$ 6-DMAP. Parthenotes were cultured in the presence of 6-DMAP as described above, either for 4 or $5 \mathrm{~h}$, according to the treatment.

In vitro culture. After incubation with 6-DMAP, all p-Zy were washed three times with BOWASH. Ten $\mathrm{p}-\mathrm{Zy}$ were allocated in droplets of $10 \mu \mathrm{L}$ of BO-IVC medium. The p-Zy were then cultured at $38.5^{\circ} \mathrm{C} / 6 \% \mathrm{O}_{2} / 6 \% \mathrm{CO}_{2} / 88 \% \mathrm{~N}_{2}$, and parthenogenetic cleavage was assessed at $96 \mathrm{hPA}$. All parthenotes continued in IVC until 192 hPA. At this last time point, visual evaluation was performed for blastocyst formation, expansion, and hatching (hatching considered the sum of hatching and hatched blastocysts).

Experimental design. It was determined the effect of two distinct periods of IVM (22-, $24 \mathrm{~h})$, as well as that of two different lengths (4-, $5 \mathrm{~h}$ ) of 6-DMAP incubation, on parthenogenetic development. Consequently, the treatments were the following: a) Control, 22 h IVM/4 h 6-DMAP; b) 22 h IVM/5 h 6-DMAP; c) $24 \mathrm{~h} \mathrm{IVM/4} \mathrm{h} \mathrm{6-DMAP;} \mathrm{and} \mathrm{d)} 24 \mathrm{~h}$ IVM/5 h 6-DMAP. Five replicates were used for the Control treatment, and six for all the other groups. All replicates were employed for parthenogenetic developmental evaluation at both the cleavage and blastocyst stages.

Statistical analysis. The statistical package GraphPad Prism 8.0.0 for Windows (GraphPad Software; San Diego, CA; www.graphpad.com) was used. All data were expressed as mean percentage \pm SEM. The effect of the treatment (duration of IVM and incubation with 6-DMAP) was evaluated by one-way analysis of variance (ANOVA), followed by a Tukey test as a post hoc analysis, to compare the means of all the treatments. A value of $\mathrm{P} \leq 0.05$ was deemed significant.

\section{Results}

In this study, it was possible to produce bovine parthenotes able to cleave (Fig. 1) and progress up to blastocyst formation, expansion, and hatching (Fig. 2).

As shown in Fig. 3A-F, no significant differences were detected in most of the developmental parameters evaluated, including: Cleavage; parthenotes of 8 to 16 cells $(8-16 \mathrm{C})$; total blastocysts (Blast.); blastocysts able to expand considering the number of COCs placed into IVM (Exp./COCs IVM); hatching (or hatched) blastocysts considering the number of COCs into IVM (Hatch./COCs IVM); or blastocysts able to expand considering the number of total blastocysts (Exp./Blast.). Nevertheless, the treatment (duration of IVM and incubation with 6-DMAP) showed a significant effect $(\mathrm{P}<0.05$; Fig. $3 \mathrm{G})$ on the hatching rate considering the number of blastocysts (Hatch./ Blast.).

In detail, as shown in Fig. 3G, group b) $22 \mathrm{~h}$ IVM/5 h 6-DMAP showed a significantly higher $(\mathrm{P}<0.05)$ percentage of Hatch./Blast. (45.89 $\pm 12.59 \%)$ when compared against c) $24 \mathrm{~h} \mathrm{IVM} / 4 \mathrm{~h}$ 6-DMAP $(6.67 \pm$ $6.67 \%)$. 


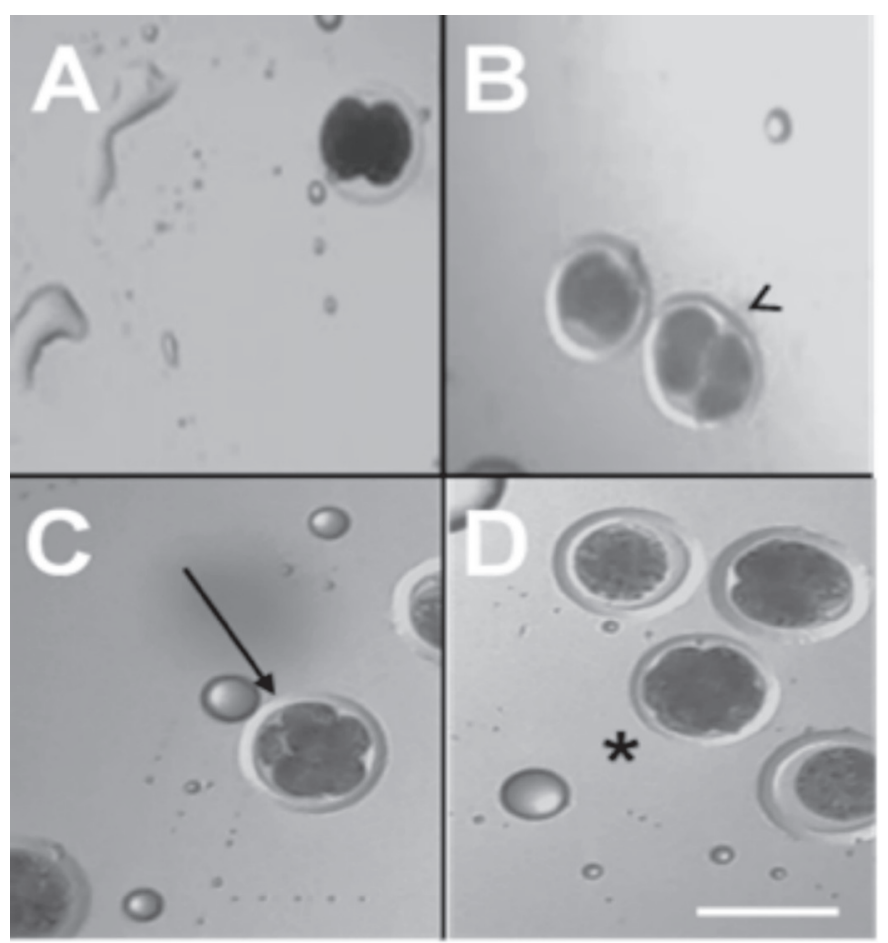

Fig. 1. Bovine parthenotes during the cleavage stage. Cumulus-oocyte complexes were matured in vitro during 22 h. Upon activation, eggs were incubated during $4 \mathrm{~h}$ with 6-dimethylaminopurine. A, 2-cell parthenote; B, 4-cell (arrowhead); C, early 8-cell (early was considered when 5 to 8 cells; arrow); D, late 8-cell (late when 10 to 16 cells; asterisk). Scale bar $=120 \mu \mathrm{m}$

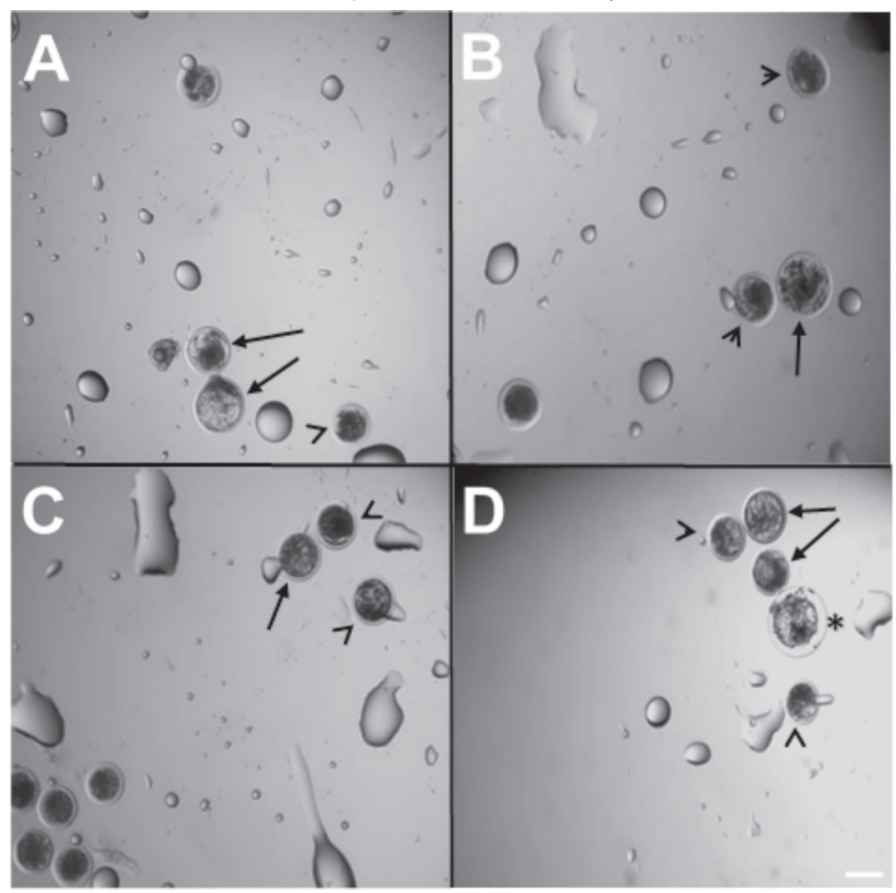

Fig. 2. Bovine parthenogenetic blastocysts generated after distinct periods of in vitro maturation (IVM) and incubation with 6-dimethylaminopurine. A, Control: $22 \mathrm{~h}$ of IVM and $4 \mathrm{~h}$ of incubation with 6-dimethylaminopurine (6-DMAP); B, 22 h IVM/5 h 6-DMAP; C, 24 h IVM/4 h 6-DMAP; D, 24 h IVM/5 h 6-DMAP. Arrowhead, early blastocyst; arrow, expanded blastocyst; asterisk, hatching blastocyst. Scale bar $=120 \mu \mathrm{m}$. 

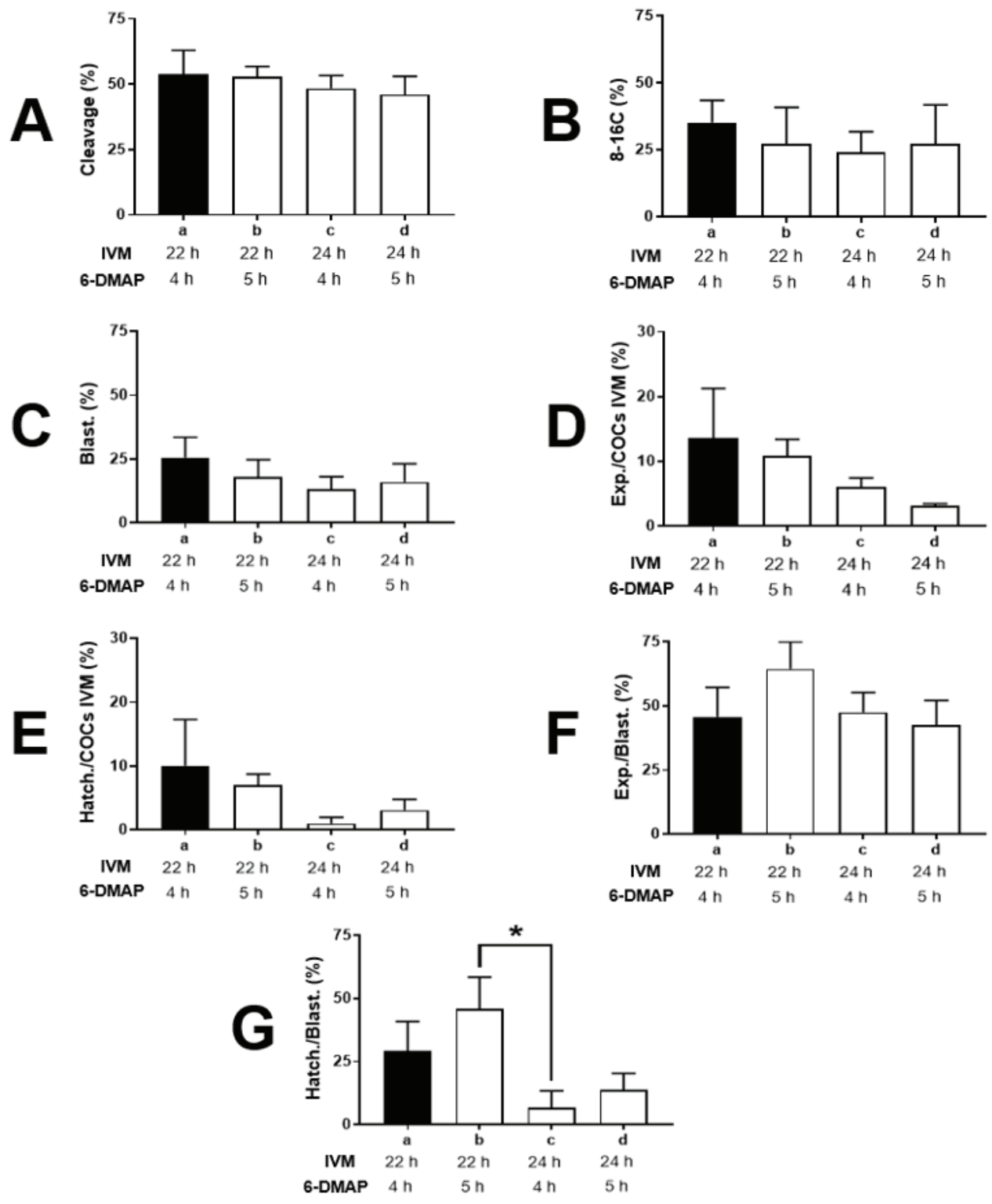

Fig. 3. Parthenogenetic development after distinct periods of in vitro maturation (IVM) and incubation with 6-dimethylaminopurine. A, cleavage percentage; B, the percentage of parthenotes with 8 to 16 cells (8-16C). $\mathrm{C}$, total blastocyst percentage (Blast.); D, the percentage of blastocysts able to expand considering the number of cumulus-oocyte complexes placed into IVM (Exp./COCs IVM). E, the percentage of hatching (or hatched) blastocysts considering the number of COCs placed into IVM (Hatch./COCs IVM); F, the percentage of blastocysts able to expand considering the number of total blastocysts (Exp./Blast.); G, the percentage of hatching (or hatched) blastocysts considering the number of total blastocysts (Hatch./Blast.). One-way analysis of variance (ANOVA) detected a significant effect $(\mathrm{P}<0.05)$ of the treatment on Hatch./Blast. rate, whereas a Tukey test showed significant differences between experimental groups $\mathrm{b}$ and $\mathrm{c}(\mathrm{P}<0.05)$. a, Control: $22 \mathrm{~h} \mathrm{IVM}$ and $4 \mathrm{~h}$ of post-parthenogenetic activation incubation with 6-dimethylaminopurine (6-DMAP). $\mathrm{n}=178 \mathrm{COCs}, \mathrm{n}=45$ Blast.; $\mathrm{b}, 22 \mathrm{~h}$ IVM $/ 5 \mathrm{~h}$ 6-DMAP. $\mathrm{n}=226$ COCs, $\mathrm{n}=40$ Blast.; c, 24 h IVM/4 h 6-DMAP. $\mathrm{n}=212$ COCs, $\mathrm{n}=28$ Blast.; $\mathrm{d}, 24 \mathrm{~h}$ IVM/5 h 6-DMAP. $n=197$ COCs, $n=32$ Blast. The bars show the mean \pm SEM. Significant differences were considered when $\mathrm{P} \leq 0.05(*)$. 


\section{Discussion}

In the current research, the selection of ionomycin followed by 6-DMAP as the activation procedure aimed at using an efficient method to produce bovine parthenotes. MÉO et al. (2007) reported that the conjunction of such ionophore and kinase inhibitor was the optimal condition for bovine PA. Here, we included a treatment consisting of $22 \mathrm{~h} \mathrm{IVM}$ and $4 \mathrm{~h}$ 6-DMAP as a Control group since this was the initial condition (combination of incubation times) in the work by MÉO et al. (2007), also focused on the efficiency of cattle PA systems. Thus, the present study aimed to determine the influence of different combinations of the length of IVM and kinase activity suppression on cattle parthenote development. This goal was studied in the short and long term over eight days of IVC under the most suitable conditions in our laboratory. These included an IVM period no longer than $24 \mathrm{~h}$. Moreover, several parameters, which reflect the capacity to progress to further development across species, and also specifically in cattle, were assessed. These parameters included: Cleavage (OROZCO-LUCERO et al., 2014; BOHRER et al., 2015), development to the 8-16 cell stage (GONZÁLEZ-GRAJALES et al., 2015), total blastocyst formation, and the number of blastocysts able to expand and hatch (HOELKER et al., 2006; MORATÓ et al., 2016). To the best of our knowledge, this study is one of the few monitoring bovine parthenote 8-16 cell rate, blastocyst expansion, and hatching as a response to any treatment (PARK et al., 2017; DAIGNEAULT et al., 2018). Furthermore, this report is the first focusing on the impact of the activation method on the aforementioned developmental parameters, all at once, in cow parthenotes.

Findings from MÉO et al. (2007) suggested that longer IVM renders higher cow blastocyst formation. It has been proposed that the improved performance of PA models after extended IVM is due to attainment of cytoplasmic maturation. Furthermore, it is plausible that the progressive reduction of histone kinase activity when IVM is prolonged facilitates the transition from M-II to the first mitotic cycle (WANG et al., 2008; SHIRAZI et al., 2009). On the other hand, it has been discovered that after ionophore-based activation, the exposure to a kinase activity inhibitor (like 6-DMAP, bohemine, or roscovitine) improves the outcome of parthenogenetic development (MÉO et al., 2007; PERECIN et al., 2007). Nevertheless, we did not detect any developmental advantage of parthenotes originated following $24 \mathrm{~h}$ of IVM. This may imply that this was because the extension of $2 \mathrm{~h}$ of maturation did not cause enough additional cytoplasmic changes (or a gradual decrease in kinase activity) compared to $22 \mathrm{~h}$ of IVM. Therefore, future experiments with long IVM periods, such as those of 26 and $30 \mathrm{~h}$ assayed by MÉO et al. (2007), concomitantly with more prolonged incubation with 6-DMAP, could help to elucidate if a synergistic effect can be generated. On the other hand, it is plausible that the longer kinase inhibition (and the consequent decline in MPF activity) when the 6-DMAP incubation lasted 5 instead of $4 \mathrm{~h}$, generated the observed surplus of hatching capacity (Hatch./Blast). Accordingly, BASTOS et al. (2008) described higher bovine parthenogenetic blastocyst formation upon $5 \mathrm{~h}$ of incubation with 6-DMAP, than in protocols using just $4 \mathrm{~h}$ (MÉO et al., 2007). Thus, it can be inferred that those parthenotes originated after the longer kinase inhibition had increased developmental capacity. This competence seemingly manifested late here as amplified hatching potential. Understanding the underlying physiological fundaments of these changes deserves detailed exploration in the future.

\section{Conclusions}

The length of IVM and incubation with kinase inhibitor influenced the development of parthenotes. The treatment consisting of $22 \mathrm{~h} \mathrm{IVM} / 5 \mathrm{~h}$ 6-DMAP showed increased parthenogenetic blastocyst hatching. These conditions could be applied to enhance the performance of bovine PA systems. 


\section{Acknowledgements}

Programa para el Desarrollo Profesional Docente (PRODEPSEP; Grant number UACJ-PTC-412 to EOL) and Consejo Nacional de Ciencia y Tecnología (CONACYT; Grant number INFR201501-251729 to JMCC) from Mexico supported this work. AVR was supported by Grants 5G12MD007592 and 5U54MD007592 to the Border Biomedical Research Center (BBRC) at the University of Texas at El Paso (UTEP), from the Research Centers in Minority Institutions (RCMI) program and the National Institute on Minority Health and Health Disparities (NIMHD), a component of the National Institutes of Health (NIH).

\section{References}

ANCCO, E., D. DIPAZ, C. QUISPE, K. ORIUNDO, E. MELLISHO (2015): In vitro development of bovine embryos after fertilization of oocytes using semen from different bulls. Spermova. 5, 129-133.

DOI: $10.18548 /$ aspe/0002.29

BASTOS, G. M., P. B. GONÇALVES, V. BORDIGNON (2008): Immunolocalization of the high-mobility group N2 protein and acetylated histone H3K14 in early developing parthenogenetic bovine embryos derived from oocytes of high and low developmental competence. Mol. Reprod. Dev. 75, 282-290.

DOI: $10.1002 / \mathrm{mrd} .20798$

BLONDIN, P., M. A. SIRARD (1995): Oocyte and follicular morphology as determining characteristics for developmental competence in bovine oocytes. Mol. Reprod. Dev. 41, 54-62.

DOI: $10.1002 / \mathrm{mrd} .1080410109$

BOHRER, R. C., A. R. COUTINHO, R. DUGGAVATHI, V. BORDIGNON (2015): The incidence of DNAdouble-strand breaks is higher in late-cleaving and less developmentally competent porcine embryos. Biol. Reprod. 93, 59.

DOI: 10.1095/biolreprod.115.130542

BREVINI T. A., G. PENNAROSSA, A. VANELLI, S. MAFFEI, F. GANDOLFI (2012): Parthenogenesis in non-rodent species: developmental competence and differentiation plasticity. Theriogenology 77, 766-772.

DOI: 10.1016/j.theriogenology.2011.11.010

DAIGNEAULT, B. W., S. RAJPUT, G. W. SMITH, P. J. ROSS (2018): Embryonic POU5F1 is required for expanded bovine blastocyst formation. Sci. Rep. 8, 7753.

DOI: 10.1038/s41598-018-25964-X

DE MACEDO, M. P., W. G. GLANZNER, V. B. RISSI, K. GUTIERREZ, L. CURRIN, H. BALDASSARRE, V. BORDIGNON (2019): A fast and reliable protocol for activation of porcine oocytes. Theriogenology 123, 22-29. DOI: 10.1016/j.theriogenology.2018.09.021

GONZÁleZ-GRAJAles, L. A., L. A. FAVETTA, W. A. KING, G. F. MASTROMONACO (2015): Developmental competence of 8?16-cell stage bison embryos produced by interspecies somatic cell nuclear transfer. Reprod. Fertil. Dev. 28, 1360-1368.

DOI: $10.1071 /$ RD14376

HOELKER, M., F. SCHMOLL, H. SCHNEIDER, F. RINGS, M. GILLES, D. TESFAYE, D. JENNEN, E. THOLEN, J. GRIESE, K. SCHELLANDER (2006): Bovine blastocyst diameter as a morphological tool to predict embryo cell counts, embryo sex, hatching ability and developmental characteristics after transfer to recipients. Reprod. Fertil. Dev. 18, 551-557.

DOI: $10.1071 / \mathrm{rd} 05149$

LEE, J., J. YOU, G. S. LEE, S. T. LEE, S. H. HYUN, E. LEE (2018): Combined treatment with demecolcine and 6-dimethylaminopurine during postactivation improves developmental competence of somatic cell nuclear transfer embryos in pigs. Anim. Biotechnol. 29, 41-49.

DOI: $10.1080 / 10495398.2017 .1294598$

MÉO, S. C., W. YAMAZAKI, C. R. FERREIRA, F. PERECIN, N. Z. SARAIVA, C. L. LEAL, J. M. GARCIA (2007): Parthenogenetic activation of bovine oocytes using single and combined strontium, ionomycin and 6-dimethylaminopurine treatments. Zygote 15, 295-306.

DOI: $10.1017 / \mathrm{S} 0967199407004285$

MORATÓ, R., M. CASTILlO-MARTÍN, M. YESTE, S. BONET (2016): Cryotolerance of porcine in vitroproduced blastocysts relies on blastocyst stage and length of in vitro culture prior to vitrification. Reprod. Fertil. Dev. 28, 886-892.

DOI: $10.1071 /$ RD14203

MUÑOZ, M., G. PENAROSSA, J. N. CAAMAÑO, C. DÍEZ, T. A. BREVINI, E. GÓMEZ (2015): Research with parthenogenetic stem cells will help decide whether a safer clinical use is possible. J. Tissue Eng. Regen. Med. 9, 325331.

DOI: 10.1002/term.1779

NAKAMURA, Y., K. KIKUCHI (2017): Utilization of porcine in vitro-produced parthenogenetic embryos for co-transfer with vitrified and warmed embryos. Anim. Sci. J. 88, 19251933.

DOI: $10.1111 /$ asj.12869

NIE, Z. W., Y. J. NIU, W. ZHOU, Y. H. KIM, K. T. SHIN, X. S. CUI (2019): Thiamethoxam inhibits blastocyst expansion and hatching via reactive-oxygen species-induced G2 checkpoint activation in pigs. Cell Signal. 53, 294-303.

DOI: 10.1016/j.cellsig.2018.08.014

OROZCO-LUCERO, E., I. DUFORT, C. ROBERT, M. A. SIRARD (2014): Rapidly cleaving bovine two-cell embryos have better developmental potential and a distinctive mRNA pattern. Mol. Reprod. Dev. 81, 31-41.

DOI: $10.1002 / \operatorname{mrd} .22278$

PARK, M. J., E. Y. KIM, M. J. KANG, J. B. LEE, C. J. JEONG, S. P. PARK (2017): Investigation of the developmental potential and developmental kinetics of bovine 
parthenogenetic and somatic cell nuclear transfer embryos using a time-lapse monitoring system. Cell. Reprogram. $19,245-254$.

DOI: $10.1089 /$ cell.2017.0003

PERECIN, F., S. C. MÉO, C. L. V. LEAL, J. M. GARCÍA (2007): Oocyte activation and preimplantation development of bovine embryos obtained by specific inhibition of cyclin-dependent kinases. Arq. Bras. Med. Vet. Zootec. 59, 280-287.

DOI: $10.1590 /$ S0102-09352007000200002
SHIRAZI, A., A. BAHIRAEE, E. AHMADI, H. NAZARI, B. HEIDARI, S. BORJIAN (2009): The effect of the duration of in vitro maturation (IVM) on parthenogenetic development of ovine oocytes. Avicenna J. Med. Biotechnol. 1, 181-191. PMID: 23408235

WANG, Z. G., W. WANG, S. D. YU, Z. R. XU (2008): Effects of different activation protocols on preimplantation development, apoptosis and ploidy of bovine parthenogenetic embryos. Anim. Reprod. Sci. 105, 292-301. DOI: 10.1016/j.anireprosci.2007.03.017

Received: 30 October 2019

Accepted: 11 May 2020

OROZCO-LUCERO, E., B. V. OROZCO-GALINDO, J. A. QUINTERO-ELISEA, M. F. ITZA-ORTIZ, M. CHAVEZ-SOLANO, J. M. CARRERA-CHÁVEZ, A. VARELA-RAMIREZ, A. QUEZADA-CASASOLA: Utjecaj trajanja in vitro sazrijevanja i inkubacije s aktivirajućim čimbenikom na kapacitet izlijeganja goveđih partenota - kratko priopéenje. Vet. arhiv 90, 527-534, 2020.

\section{SAŽETAK}

Vrijeme in vitro sazrijevanja (IVM) i vrijeme inkubacije s aktivatorima oocista utječu na stvaranje blastocista nakon partenogenetske aktivacije (PA). Ipak, još uvijek se ne zna kako navedeno utječe na ekspanziju i stopu izlijeganja goveđih partenogenetskih blastocista. Cilj rada bio je istražiti utjecaj trajanja IVM i izloženosti aktivirajućem čimbeniku 6-dimethylaminopurinu (6-DMAP) na više razvojnih parametara u goveđih partenota, uključujući diobu, formiranje blastociste, ekspanziju i izlijeganje. Oocite prikupljene u klaonicama bile su podvrgnute različitom trajanju IVM. Nakon toga jajašca su prvo partenogenetski aktivirana s ionomicinom kroz 5 minuta i nakon toga inkubirana tijekom određenih vremenskih razdoblja sa drugim aktivatorom, 6-DMAP. Protokoli po istraženim skupinama bili su sljedeći: a) kontrolna skupina 22 h IVM/4 h 6-DMAP, b) skupina 22 h IVM/5 h 6-DMAP, c) skupina 24 h IVM/4 h 6-DMAP i d) skupina 24 h IVM/5 h 6-DMAP. Razvojni stadiji in vitro kulture (IVC) procijenjivani su 4. i 8. dan. Za većinu razvojnih parametara nisu utvrđene razlike između istraženih skupina. Ipak, trajanja IVM i inkubacije sa 6-DMAP znakovito su utjecali $(\mathrm{P}<0,05)$ na kapacitet izlijeganja kad se u obzir uzme broj blastocista (izlijeganja/ blasociste). Također, isti pokazatelji bili su viši $(\mathrm{P}<0,05)$ u skupini b) $22 \mathrm{~h} \mathrm{IVM/5} \mathrm{h} \mathrm{6-DMAP}(45,89 \pm 12,59 \%) \mathrm{u}$ odnosu na skupinu c) 24 h IVM/4 h 6-DMAP (6,67 $\pm 6,67 \%)$. Zaključno, trajanje IVM i inkubacije sa 6-DMAP utjecali su na partenogenetski razvoj, pri čemu je 22 h IVM/5 h 6-DMAP kombinacija koja u goveđih partenota proizvodi najvišu stopu za pokazetelj izlijeganje/blasociste.

Ključne riječi: sazrijevanje in vitro; 6-dimetilaminopurin; trajanje kulture; vrijeme inkubacije, partenogeneza; goveda 